$\mathbb{T}$ periodica polytechnica

\author{
Transportation Engineering

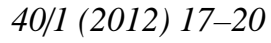 \\ doi: 10.3311/pp.tr.2012-1.03 \\ web: http://www.pp.bme.hu/tr \\ (c) Periodica Polytechnica 2012
}

RESEARCH ARTICLE

\section{The development of a complex city logistics cost model according to a multiple-stage gateway concept}

\author{
András Bakos / Krisztián Bóna / Szilvia Foltin
}

Received 2012-09-27

\begin{abstract}
This article aims to describe a strategic model of the operation of the goods supply of an arbitrarily structured city. It introduces the elements and structure of the model and elaborates its operation. The city logistics notion, that the advantages of the consolidation of the goods due the city centre outweigh the disadvantages that of, is examined. Alternatives, differing from organization and technology, are compared using total cost functions; their effect to their surroundings is also estimated.
\end{abstract}

\section{Keywords}

city logistics $\cdot$ decision-making $\cdot$ modelling $\cdot$ supply chain . urban distribution

\section{Acknowledgement}

This work is connected to the scientific program of the 'Development of quality-oriented and harmonized REDEI strategy and functional model at BME' project. This project is supported by the New Széchenyi Plan (Project ID: TÁMOP-4.2.1/B09/1/KMR-2010-0002).

\section{András Bakos}

Department of Material Handling and Logistics Systems, BME, H-1111 Budapest, Hungary

e-mail: andras.bakos@logisztika.bme.hu

\section{Krisztián Bóna}

Department of Material Handling and Logistics Systems, BME, H-1111 Budapest, Hungary

e-mail: kbona@kku.bme.hu

\section{Szilvia Foltin}

Department of Transportation Technology, BME, H-1111 Budapest, Hungary e-mail: foltin.szilvi@gmail.com

\section{The basics of the modelling}

By city logistics, we mean the technically, economically, organizationally efficient and environmentally friendly synchronization of goods distribution (and reverse logistics) tasks generated mainly by the secondary and tertiary sectors, and mostly retailers in downtown areas and historical city centres [1]. There are many best practices to be found worldwide, that have already been identified and classified ([2]; [3] ). Different city logistics system solutions affect the goods distribution of a city in various ways and magnitude, thus a model is desirable that helps the decision-making of stakeholders.

We are examining the indicators of cities housing city logistics system solutions, and some that are lacking those. The problem with the latter is that the shops, that form the demand scattered throughout the city, are not visited by their suppliers in a coordinated fashion, taking advantage of the common capacity, but rather they compete. Satisfying the demand takes place with presumably sub-optimal logistics-related costs. This comes from the different suppliers transporting same types of goods to the same destinations with different - redundant - infrastructure, which could be avoided, according to Kovács [4]. Moreover, the attributes of the supply chains are adjusted to the regulation of the given municipality, but they seldom take advantage of certain possibilities (e.g. river, railways), and usually do not utilize integrated solutions, preferring road to multimodal transportation.

In order to assess the possibilities, we are developing a model that can compare various scenarios. The model is constantly evolving, but its fundamentals are: it maps an area with a graph, generates variable demand, and compares total costs.

The model is basically static in structure: the different alternatives are constituted by nodes, and the transport system between each of these nodes. The demand is stochastic: the destinations and their daily demand (quantity of goods ordered) is a random variable. The total demand has to be satisfied with a - a priori unknown - number of vehicles.

The common elements of the solutions are the location of the suppliers (LS), the urban consolidation centres (UCC), the urban relay stations (URS), and the urban loading points (ULP). 
Tab. 1. Elements of a city logistics network

\begin{tabular}{llll}
\hline Element & Type & Vehicle & Function \\
\hline Location of suppliers (LS) & Node & & Source of goods \\
\hline Long-distance transport paths & Edge & Regional vehicles & Large-scale, homogeneous goods transport \\
\hline Urban consolidation centres (UCC) & Node & & Consolidation \\
\hline Main urban transport paths & Edge & Local vehicles & Large-scale, heterogeneous goods transport \\
\hline Urban relay stations (URS) & Node & & Fast transhipment \\
\hline Feeder urban transport paths & Edge & Last mile vehicles & Small-scale, heterogeneous goods transport \\
\hline Urban loading points (ULP) & Node & & Sink, points of sale \\
\hline
\end{tabular}

The number and location of these varies with each alternative. Further variable elements are the local and regional transport systems, with different vehicles and tracks ([5]; [6]). Accordingly, the model consists of a network, modelled as a graph (see Table 1). This structure of the model is suitable for the present and the planned systems, so they can be compared.

\section{Expected impacts}

The first step in order to compare the impact of the individual alternatives is to methodize the factors that significantly affect the supply of a city. This model concentrates to the logistics cost drivers, which are functions of the logistics performance [7]. In the initial phase it further concentrates to operational factors, but later it will be possible to include other (not necessarily operational) costs as well. Transport, loading and storage costs are identified in this network. Investment costs are excluded here, only the costs related to the continuous operation are included. These are primarily fixed and variable costs coming from the operation of the infrastructure and the execution of the daily tasks. The costs in Table 2 and Eq. (??) are deduced from these.

Tab. 2. The costs examined

\begin{tabular}{lllc}
\hline Element & Loading & \multicolumn{2}{c}{ Transport Storage } \\
\hline Location of suppliers (LS) & $\mathrm{C}_{h}^{L}$ & & {$\left[\mathrm{C}_{h}^{S}\right]$} \\
$\begin{array}{l}\text { Long-distance transport paths } \\
\text { Urban consolidation centres (UCC) }\end{array}$ & $C_{i}^{L}$ & $\mathrm{C}_{h i}^{T}$ & $C_{i}^{S}$ \\
$\begin{array}{l}\text { Main urban transport paths } \\
\text { Urban relay stations (URS) }\end{array}$ & $C_{j}^{L}$ & $C_{i j}^{T}$ & \\
Feeder urban transport paths & & $C_{j k}^{T}$ & \\
Urban loading points (ULP) & $C_{k}^{L}$ & & \\
\hline
\end{tabular}

$$
\begin{aligned}
C & =\sum_{h=1}^{X} X_{h} \cdot\left(C_{h}^{L}+\left[C_{h}^{S}\right]\right)+\sum_{h=1}^{X} \sum_{i=1}^{Y} X_{h i} \cdot C_{h i}^{T}+ \\
& \sum_{i=1}^{Y} X_{i} \cdot\left(C_{i}^{L}+C_{i}^{S}\right)+\sum_{i=1}^{Y} \sum_{j=1}^{Z} X_{i j} \cdot C_{i j}^{T}+ \\
& \sum_{j=1}^{Z} X_{j} \cdot\left(C_{j}^{L}+\left[C_{j}^{S}\right]\right)+\sum_{j=1}^{Z} \sum_{k=1}^{V} X_{j k} \cdot C_{j k}^{T}+\sum_{k=1}^{V} X_{k} \cdot C_{k}^{L}
\end{aligned}
$$

where
$X_{l} \quad$ and $\quad X_{m n}= \begin{cases}1 & \text { if the given node or edge is part } \\ \text { of the network } & \text { if not }\end{cases}$

During the execution of the daily tasks, transport performances are generated on the edges of the network. Beside these, external costs of transport and other fixed and variable (function of distance travelled or number of vehicles) costs related to the maintenance of the vehicles, road pricing and environmental impact can be taken into consideration.

The needed performance for the execution of the tasks on the nodes can be attributed to the consolidation (the picking of the goods by destinations and product categories), creation of unitloads, loading of the vehicles, cross-docking, transhipment, unloading at the destinations and reverse logistics. During the calculation of the loading and storage costs, it is recommended to begin with the fixed and variable costs of these, and from the usage of the infrastructure. The loading costs are calculated in , and the storage costs in .

Apart from all the above costs, indicators can be attributed to transit times, investment needs (number of vehicles, consolidation centres, relay stations etc.), inventory, reliability. Only estimates are present as to the expected results and impacts. The rationalization of the transport system suggests e.g. the reduction of the transport performance and thus the transport costs, external costs. However, the complex loading and storage tasks can implicate mounting loading and storage costs.

\section{Estimated order of magnitude}

Three alternatives are introduced for the estimation of the provisional impacts:

- one urban consolidation centre, road transport,

- one urban consolidation centre, railway feed,

- one urban consolidation centre, waterway feed.

This way the effect of the different types of vehicles can be seen. The estimation is based on the following data:

- $\mathrm{N}$ : the number of destinations; 
- $\mathrm{h}$ : the average distance between the destinations and the UCC;

The location of the destinations is an even random variable inside the service area (in this case an ellipse)

- $\mathrm{C}$ : the maximum number of stops a vehicle can make depending on the loading and transport times;

- A: the size if the service area;

- $\delta$ : the density of the destinations, $\delta=\mathrm{N} / \mathrm{A}$;

- L: the total distance travelled by the vehicles, to be calculated.

\section{A. Single UCC, road transport}

The total distance travelled during the centralized distribution of the planned system solution is calculated according to [8]:

$$
L=2 h \cdot N / C+0.57 \cdot N \cdot \delta^{-1 / 2}
$$

With pure road transportation in the inner areas the costs to be calculated are:

$$
\begin{gathered}
C=\sum_{h=1}^{X} X_{h} \cdot\left(C_{h}^{L}+\left[C_{h}^{S}\right]\right)+\sum_{h=1}^{X} X_{h ; i=1} \cdot C_{h ; i=1}^{T}+C_{i=1}^{L}+C_{i=1}^{S}+ \\
\sum_{k=1}^{V} X_{j=1 ; k} \cdot C_{j=1 k}^{T}+\sum_{k=1}^{V} X_{k} \cdot C_{k}^{L}
\end{gathered}
$$

\section{B. Single UCC, waterway feed}

In case that the feeder route is water based, the destinations are reached via an urban relay station. Eq. (5) is altered, because the round-trip between the UCC and the URS need only be travelled once (provided the capacity of the boat is large enough for this):

$$
L=2 h+0.57 \cdot N \cdot \delta^{-1 / 2}
$$

\section{Single UCC, railway feed}

In case that the feeder route is railway based, the goods are transported to an URS located at the perimeter of the service area. The round-trip between the UCC and the URS need only be travelled once. From the URS, road vehicles distribute the goods, they need to cover shorter routes - the difference is the distance between the UCC and the URS, see Eq. (??):

$$
L=2 h_{1}+2\left(h-h_{1}\right) \cdot N / C+0.57 \cdot N \cdot \delta^{-1 / 2}
$$

The total cost function - both in the case of waterway and railway feed - is the following:

$$
\begin{gathered}
C=\sum_{h=1}^{X} X_{h} \cdot\left(C_{h}^{L}+\left[C_{h}^{S}\right]+\sum_{h=1}^{X}\right) X_{h ; i=1} \cdot C_{h ; i=1}^{T}+C_{i=1}^{L}+C_{i=1}^{S}+ \\
\left.\left.C_{i=1 ; j=1}^{T}+C_{j=1}^{L}+C_{j=1}^{S}+\sum_{k=1}^{V}\right) X_{j=1 ; k} \cdot C_{j=1 k}^{T}+\sum_{k=1}^{V}\right) C_{k}^{L}
\end{gathered}
$$

\section{Present state}

It is essential to be able to compare the planned system solutions to the original state of the goods supply of a city. In that case, the total distance travelled is calculated according to [9]:

$$
L=n \cdot 0.75 \cdot(N A)^{1 / 2}
$$

- $\mathrm{N}$ : the stops made by one vehicle in the original scenario;

- $\mathrm{n}$ : the number of vehicles originally used for the goods supply of a city.

$$
\left.\left.\left.C=\sum_{h=1}^{X} C_{h}^{L}+\left[C_{h}^{S}\right]+\sum_{h=1}^{X}\right) C_{h k}^{T}\right)+\sum_{k=1}^{V}\right) C_{k}^{L}
$$

According to the initial results, distributing the same amount of goods from a consolidation centre can reduce the present, calculated distance travelled to two thirds of the original. Further savings can be achieved if the route between the city centre and the UCC is not covered on road, that is signed by $2 h \frac{N}{C}$ in Eq. (2), but instead on rail or water, and only the last mile distribution is done on road.

Reduction of the transport costs can be achieved in this manner, but one should not forget about the resupply costs of the UCCs. The suppliers namely have to move their products to the UCCs. So as not to worsen the effectiveness of the system, the location of the UCCs should be specified as a solution of a Site Location Problem. It seems likely that a single consolidation centre located on the outskirts of a city can reduce distances travelled by suppliers also located there, or at the nearest agglomeration. The greater the number of the UCCs, the better the whole agglomeration can be covered. The question is, what about suppliers located downtown, when is it worth it for them to join the system? It should be noted, though, that the ratio of suppliers downtown tend to be low.

\section{Conclusion}

The greatest challenge that can help the application of the model is the acquisition of more precise unit costs derived from logistics performance. External costs should later be included next to the existing ones, because a primary goal of a city logistics system solution is the reduction of the air and noise pollution and the augmentation of the standards of living. The finetuning of the model should produce precise enough results that can point out an advantage of a specific alternative. The model, since it was developed generally, can be used extensively and in a wide number of cities and urban areas: the model parameters can be modified so as it can help decision-making at different locations.

\section{References}

1 Bakos, A Modern Freight Distribution Model for Urban Areas, Proceedings of International Conference on Innovative Technologies, pp. 726-727. INTECH Conference, 2011. 09.01-03. 
2 Bóna, Bakos, Budapesten city logisztika? Lehetséges!, Logisztikai Híradó (2011), no. 2, 18-25. MLBKT, Budapest.

3 Bóna, Külföldi városellátási gyakorlatok tapasztalatai a magyarországi nagyvárosokban történố alkalmazhatóság szempontjából, Logisztikai Évkönyv ( 2010), 86-93. MLE.

4 Kovács G, Possible methods of application of electronic freight and warehouse exchanges in solving the city logistics problems, Periodica Polytechnica ser. Transport Engineering 38 (2010), no. 1, 25-28, DOI 10.3311/pp.tr.2010-1.05.

5 Bóna, Korszerú technológiai megoldások a városközpontok áruellátásának szervezésében - 3. rész, Tranzit magazin (2011), no. 3, 43-45.

6 Bóna, Korszerú technológiai megoldások a városközpontok áruellátásának szervezésében - 4. rész, Tranzit magazine (2011), no. 3, 46-48.

7 Bokor Z, Calculation model for transport costing, Periodica Polytechnica ser. Transport Engineering 39 (2011), no. 1, 43-47, DOI 10.3311/pp.tr.20111.08 .

8 Robuste, Daganzo, Souleyrette, Implementing vehicle routing models, Transportation Res. B 24B. (1990), 263-286.

9 Stein, An asymptotic probabilistic analysis of a routing problem, Math. Ops Res. 3. (1978), 89-101. 